\title{
ORGANOMETALLIC AND SURFACE CHEMISTRY OF MIXED-METAL SYSTEMIS
}

Progress Report

for Period March 15, 1992 - March 14, 1993

\author{
D. F. Shriver
}

RFPIVED

MAY 071993

Northwestern University

Evanston, IL 60208-3113

\section{OSTI}

\section{NOTICE}

This report was prepared as an account of work sponsored by the United States Government. Neither the United States nor the Department of Energy, nor any of their employees, nor any of their contractors, subcontractors, or their employees, makes any warranty, express or implied, or assumes any legal liability or responsibility for the accuracy, completeness, or usefulness of any information, apparatus, product or process disclosed or represents that its use would not infringe privately-owned rights.

April, 1993

Prepared for

THE U.S. DEPARTMENT OF ENERGY

AGREEMENT NO. DE-FG02-86ER13640

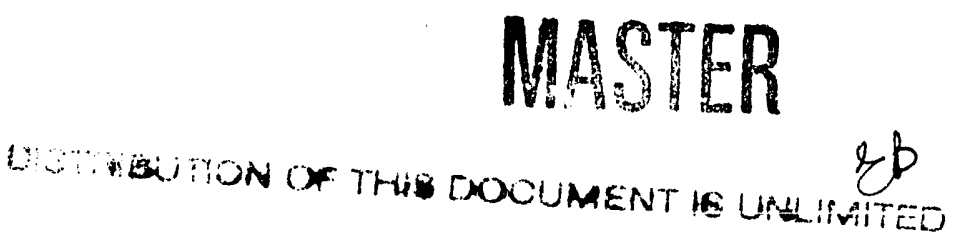




\begin{abstract}
Three new $\mathrm{SO}_{2}$ complexes of metal cluster compounds were prepared: $[\mathrm{PPN}]\left[\mathrm{HFe}_{3}(\mathrm{CO})_{9} \mathrm{SO}_{2}\right],[\mathrm{PPN}]_{2}\left[\mathrm{Ru}_{3} \mathrm{CO}_{9} \mathrm{SO}_{2}\right]$ and $[\mathrm{PPN}]_{2}\left[\mathrm{Ru}_{3}(\mathrm{CO})_{7}\left(\mathrm{SO}_{2}\right)_{3}\right]$. The $\mathrm{x}-$ ray structures were determined for two of these and the transformation of bound $\mathrm{SO}_{2}$ to cluster bound $\mathrm{SO}$ and $\mathrm{S}$ ligands was investigated.
\end{abstract}

\title{
Progress
}

One of our current research goals is to gain basic information about the reaction patterns displayed by $\mathrm{SO}_{2}$ in clusters. Of special interest is the reductive cleavage of $\mathrm{SO}_{2}$. By analogy with our findings in CO chemistry one approach is to explore the electrophilic attack at the oxygen of cluster-bound $\mathrm{SO}_{2}$ and the subsequent reductive cleavage of the S-O bond. Another point under investigation is the modes of bonding of $\mathrm{SO}_{2}$ to tri and higher nuclearity clusters of group 8 metals.

A graduate student on this DOE-sponsored research, Gail Karet, has found that sulfur dioxide reacts with $[\mathrm{PPN}]_{2}\left[\mathrm{HFe}_{3}(\mathrm{CO})_{11}\right]$, to produce the cluster $[\mathrm{PPN}]\left[\mathrm{HFe}_{3}(\mathrm{CO})_{9} \mathrm{SO}_{2}\right]$, for which the $x$-ray crystal structure reveals the unusual $\mu_{3}, \eta^{2}-\mathrm{SO}_{2}$ bonding pattern, I. This $\mathrm{SO}_{2}$ ligand exhibited one very long S-O distance of $1.62(1) \AA$ and one shorter distance $\left(1.434(9) \AA\right.$ ) which was nearly the $\mathrm{S}-\mathrm{O}$ distance found in free $\mathrm{SO}_{2}$. The cluster $[\mathrm{PPN}]_{2}\left[\mathrm{Ru}_{3}(\mathrm{CO})_{11}\right]$ was found to react with $\mathrm{SO}_{2}$ to produce two different $\mathrm{SO}_{2}$ clusters, $[\mathrm{PPN}]_{2}\left[\mathrm{Ru}_{3}(\mathrm{CO})_{9} \mathrm{SO}_{2}\right]$ and $[\mathrm{PPN}]_{2}\left[\mathrm{Ru}_{3}(\mathrm{CO})_{7}\left(\mathrm{SO}_{2}\right)_{3}\right]$. The x-ray structure of the former again reveals the presence of the $\mu_{3}, \eta^{2}-\mathrm{SO}_{2}$ ligand. The IR and ${ }^{13} \mathrm{C} N \mathrm{NMR}$ spectroscopy of the latter indicate the presence of one $\mu_{3}, \eta^{2}-\mathrm{SO}_{2}$ ligand and two more conventionally bonded $\mathrm{SO}_{2}$ ligands that bridge $\mathrm{Ru}$ atoms through sulfur. The only other $\mathrm{SO}_{2}$ complexes of anionic clusters were prepared several years ago in our laboratory by Paula Bogdan. The attraction of anionic $\mathrm{SO}_{2}$ clusters is their potential reactivity with nucleophiles on the $\mathrm{O}$ atom in a manner analogous to the extensive chemistry of $\mathrm{CO}$.

The cluster [PPN][HFe ${ }_{3}(\mathrm{CO})_{9} \mathrm{SO}_{2}$ ] reacts with acetyl chloride to form a species, which appears to contain S-O-Ac. Reduction of this species leads to the formation of the known cluster $[\mathrm{PPN}]_{2}\left[\mathrm{Fe}_{3}(\mathrm{CO})_{9} \mathrm{~S}\right]$ with cleavage of both $\mathrm{S}-\mathrm{O}$ bonds. The infrared and ${ }^{13} \mathrm{C} \mathrm{NMR}$ spectra of the product of the reduction were found to match those in the literature for 
$[\mathrm{PPN}]_{2}\left[\mathrm{Fe}_{3}(\mathrm{CO})_{9} \mathrm{~S}\right]$. Reduction of $\mathrm{I}$ without prior acetylation leads to cleavage of only one S-O bond to form the cluster [PPN][Fe $e_{3}(\mathrm{CO})_{9} \mathrm{SO}$ ] in moderate yields. This compound, which was characterized by $\mathrm{x}$-ray diffraction, provides a rare example of $\mathrm{SO}$ bound to a cluster.

The reactions of anionic metal clusters containing $\mathrm{SO}_{2}$ is indeed rich with reactions involving the $\mathrm{SO}_{2}$ ligand. Further studies are under way to explore the scope of this chemistry. Special attention will be paid to role of multimetal binding and $O$ bonding in the transformations of $\mathrm{SO}_{2}$.

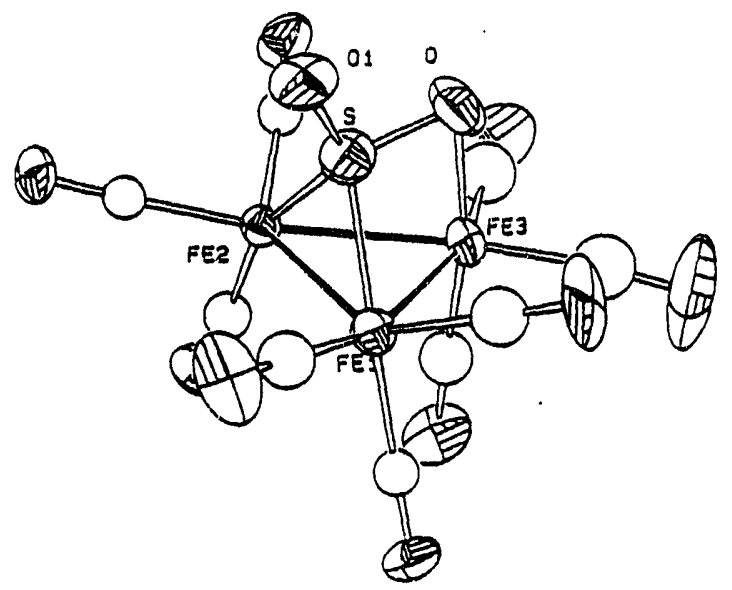




\section{DOE SUPPORTED PUBLICATIONS 1992}

1. "CC and CO Transformations in Ketenylidene Cluster Compounds", M. P. Jensen and D. F. Shriver, J. Mol. Catal., 74, 73-84 (1992), previously listed as in press.

2. "Mass Spectroscopic Evidence for the Formation of Mixed-Metal Octahedral Clusters $\left[\mathrm{Mo}_{\mathrm{n}} \mathrm{W}_{6-\mathrm{n}} \mathrm{Cl}_{14}\right]^{2-\cdots}, \mathrm{H}$. A. Hodali, H. Hung and D. F. Shriver, Inorg. Chimica Acta, 198 249 (1992); previously listed as in press.

3. "Syntheses of the Seven Metal Carbide Cluster $[\mathrm{PPN}]_{2}\left[\mathrm{Os}_{3} \mathrm{Ni}_{4} \mathrm{C}(\mathrm{CO})_{15}\right]$ and of $[\mathrm{PPN}]_{2}\left[\mathrm{Os}_{3} \mathrm{Ni}_{3} \mathrm{C}(\mathrm{CO})_{13}\right]$ ", G. B. Karet, R. L. Espe, C. L. Stern and D. F. Shriver, Inorg. Chem., 31,2658 (1992).

4. "Structure, Conductivity and Raman Spectrum of 4,7,13,16-tetraoxa-1,10dithiacyclooctadecanebis(diiodine)", A. L. Tipton, M. C. Lonergan, C. L. Stern and D. F. Shriver, Inorg. Chimica Acta, 201, 23-27 (1992).

5. "Some Relationships Between Metal Cluster Chemistry and Heterogeneous Catalysis", D. F. Shriver, J. Cluster Sci., 3, No. 4, 459 (1992). 

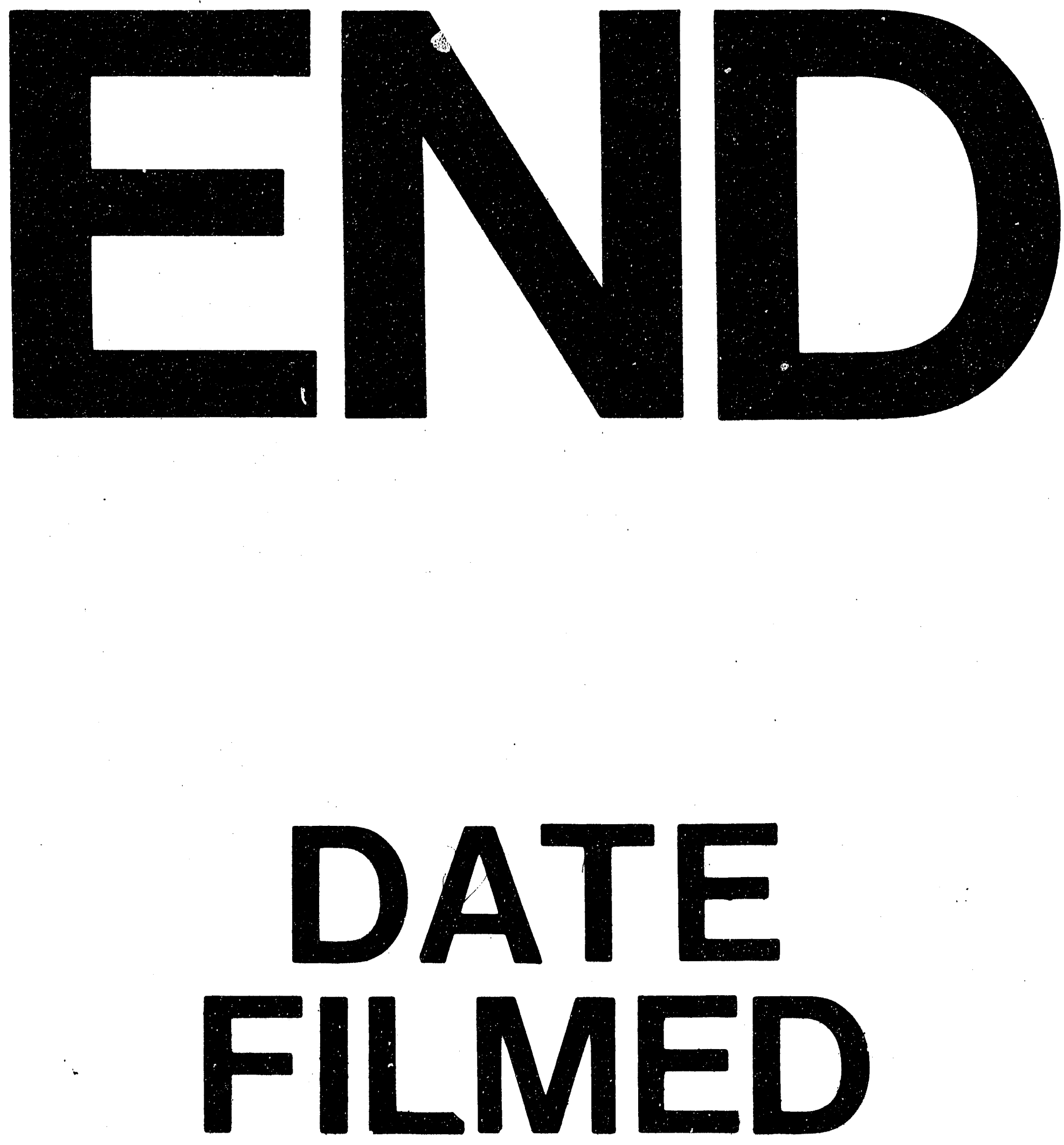

1

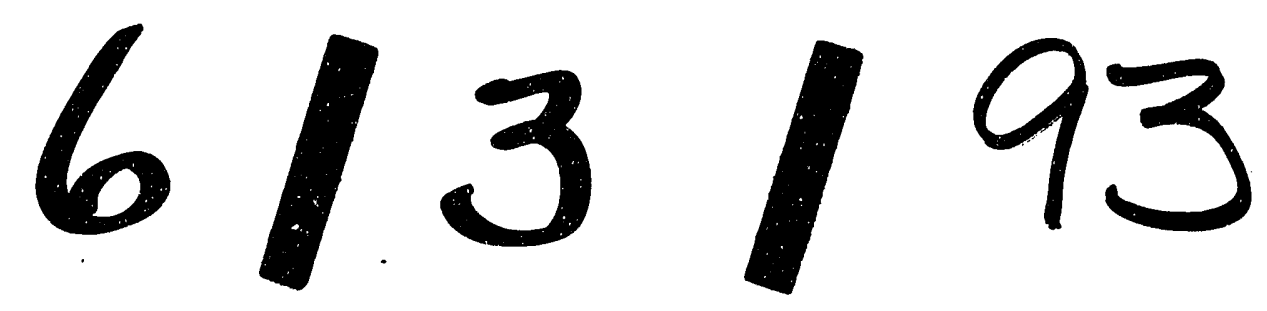


